\title{
Application of Artificial Neural Network and Background Subtraction for Determining Body Mass Index (BMI) in Android Devices Using Bluetooth
}

\author{
Neil Erick Q. Madariaga and Noel B. Linsangan
}

\begin{abstract}
Body mass index (BMI) is one of the different ways to monitor the health of a person. It is based on the height and weight of the person. This study aims to compute for the BMI using an Android tablet by obtaining the height of the person by using a camera and measuring the weight of the person by using a weighing scale or load cell. The height of the person was estimated by applying background subtraction to the image captured and applying different processes such as getting the vanishing point and applying Artificial Neural Network. The weight was measured by using Wheatstone bridge load cell configuration and sending the value to the computer by using Gizduino microcontroller and Bluetooth technology after the amplification using AD623 instrumentation amplifier. The application will process the images and read the measured values and show the BMI of the person. The study met all the objectives needed and further studies will be needed to improve the design project.
\end{abstract}

Index Terms-Artificial neural network, bluetooth, body mass index, vanishing point, wheatstone bridge load cell.

\section{INTRODUCTION}

Health consciousness is becoming a factor and important part of the Filipino consumers' life and starts preferring herbal or traditional products, invests in preventive medication and starts participating in sports activities as stated by the report by the Euromonitor International (2013). With the increasing number of health conscious Filipinos, different center for health and gym for fitness are becoming popular, even home-based body workout. There are different ways on monitoring the health and body composition of a person for their fitness which includes the Body Mass Index (BMI).

Body mass index (BMI) is a measurement of the body fat level among people. It is computed using the height and weight of a person and is related to the age of the person. BMI determines the distribution of the mass of the person with its height. There are several categories that a person could fall into base on the value of their BMI including underweight, normal weight, overweight and obesity. The increasing demands on the health conscious Filipinos resulted to the automation of different techniques in monitoring the body fat level through the computation of

Manuscript received November 14, 2014; revised April 20, 2015. This work was supported in part by the Department of Science and Technology Engineering Research and Development for Technology (DOST - ERDT).

The authors are with the Department of Electrical, Electronics, and Computer Engineering, Mapua Institute of Technology, Intramuros, Manila, Philippines (e-mail: neqmadariaga@gmail.com, nblinsangan@mapua.edu.ph).
BMI.

The weight of the person can be obtained by using a weighing scale with load cells that were configured to Wheatstone bridge. Load cells can be applied as a sensor for measuring the weight of different objects [1]. Load cells are usually used for weight measurement for food, vehicles and animals [2].

The height of the person can be computed using the camera of an Android tablet and image processing. The person or the foreground object can be extracted by removing the unwanted region or the background [3] and it is called background subtraction. Background subtraction can be implemented by using artificial neural network (ANN) for self-organizing image processing to detect objects in a scene [4]. The height of the person in the image (in pixels) can be related to its height in the real world (in meters) by getting the vanishing point of the image [5].

In this study, the weight of the person would be calculated by using a weighing scale configured to a Wheatstone bridge and calibrated in a microcontroller. The calculated weight would be sent to an Android tablet via Bluetooth connection. The height of the person would be estimated by using the images captured by the built-in camera of the Android tablet. The images will undergo background subtraction implemented using ANN to extract the image of the person. The vanishing point will be computed by getting the intersection of lines in the image.

\section{METHODOLOGY}

This part of the study shows the procedure of measuring the parameters needed to determine the Body Mass Index (BMI) of a person.

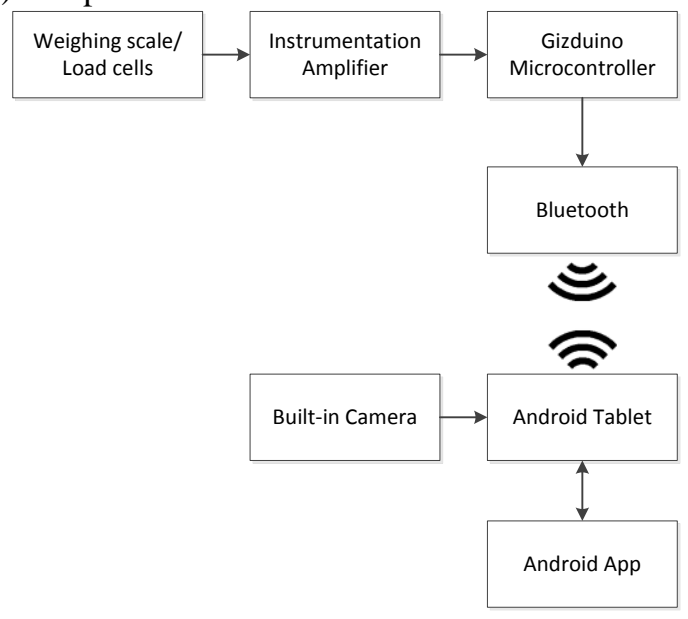

Fig. 1. Block diagram of the system. 
Fig. 1 shows the block diagram for the whole system. The diagram shows the two inputs necessary for the system, the weighing scale and the built-in camera of the Android Tablet. The Android App processes data images and the reading from the load cell to compute the BMI of the person.

\section{A. Weight Computation}

In this part of the process, the weight of the person will be computed. Fig. 2 shows the block diagram for obtaining the weight of the person.

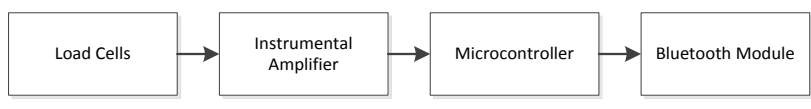

Fig. 2. Weight computation block diagram.

Wheatstone bridge load cell configuration comprises of four (4) load cells. The configuration requires positive and negative excitation voltages and produces positive and negative sense values. An instrumentation amplifier, AD623, was used to get the differential voltage of the sense values and amplifies for the microcontroller to read. The read value will be converted into its equivalent weight by equating the slopes of two points. The plot of the values obtained using a weight measuring device was linear [1]. Equation (1) can be used to get the equivalent weight of the read value.

$$
L_{x}=\frac{\left(\text { Vout }_{x}-\text { Vout }_{A}\right)\left(L_{B}-L_{A}\right)}{\text { Vout } \left._{B}-\text { Vout }_{A}\right)}+L_{A}
$$

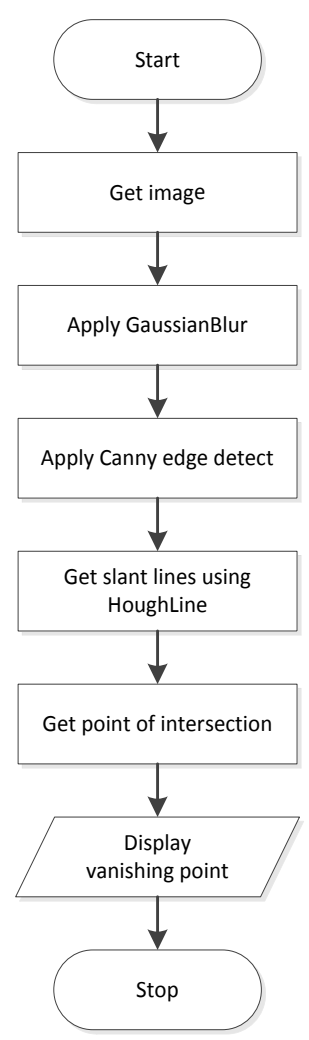

Fig. 3. Vanishing point determination flow chart.

where $L_{A}$ and $L_{B}$ are the known loads in $\mathrm{kg}$ and Vout $_{A}$ and Vout $_{B}$ are the equivalent voltages of $L_{A}$ and $L_{B}$ in volts. Vout is the output voltage of the weighing person and $L_{x}$ is the weight of the person. The computed weight will be sent to the Android tablet via Bluetooth.

\section{B. Vanishing Point and Camera Height}

In order to determine the relationship between the real world and the image, the vanishing point must be determined. Fig. 3 shows the flow chart in getting the vanishing point. The vanishing point was determined by getting the intersection of the slant lines in the image. These slant lines were all parallel lines in the real world. The intersection of these slant lines would serve as the height in the image where the camera was supposed to be positioned. Applying Gaussian blur in the image would reduce the small details in the image which means that the small lines are removed. The canny method would generate all the lines from the blurred image. Using the Hough Line transformation, all the points of the lines in the blurred image would be extracted and saved in a vector. The extracted lines were reduced into only slant lines by getting the slopes of the lines. The point of intersection of all the lines will serve as the vanishing point.

Fig. 4 shows the representation of vanishing point in an image. The image has several parallel lines on the ground and the camera captured these lines as slant lines in the image.

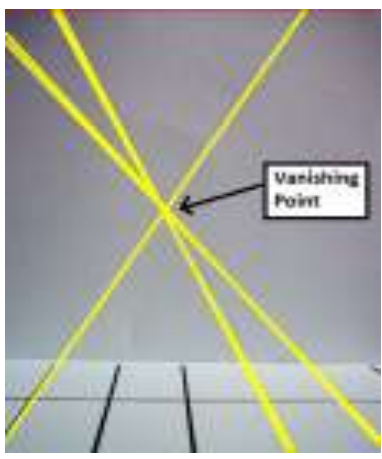

Fig. 4. Vanishing point.

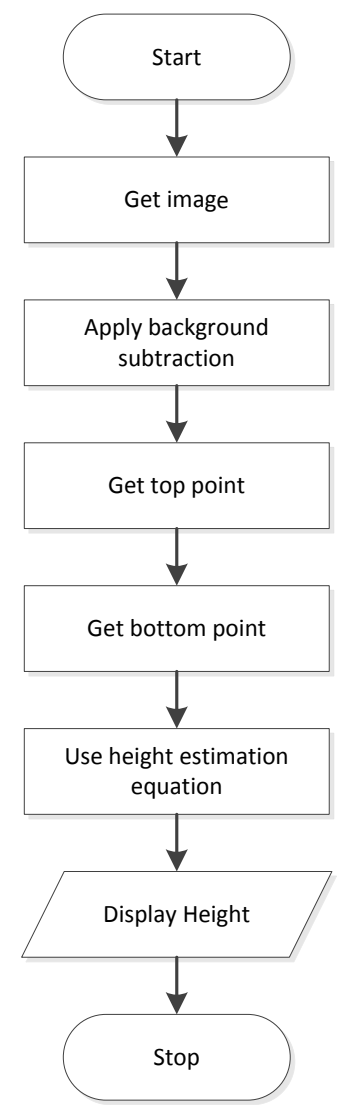

Fig. 5. Height estimation flow chart. 
The camera height can be determined by using an object with known height and the vanishing point. The camera height can be computed by manipulating (2).

$$
h_{\text {oinmecers }}=\frac{h_{\text {oinmecers }}}{Y_{v p}-Y_{b p}} \times h_{i \text { inmecers }}
$$

where $h_{o}$ is the actual height, $h_{c}$ is the camera height, $\mathrm{h}_{\mathrm{i}}$ is the height of the person in the image, $y_{v p}$ is the y-coordinate of the vanishing point in the image and $y_{b p}$ is the y-coordinate of the base point of the object in the image [5].

\section{Height Estimation}

Fig. 5 shows the flow chart for height estimation. The height estimation includes the background subtraction using the Artificial Neural Network (ANN) and determining the height of the foreground image. The vanishing point and the camera height will be used to get the actual height of the person.

The height of the person can be computed using (2).

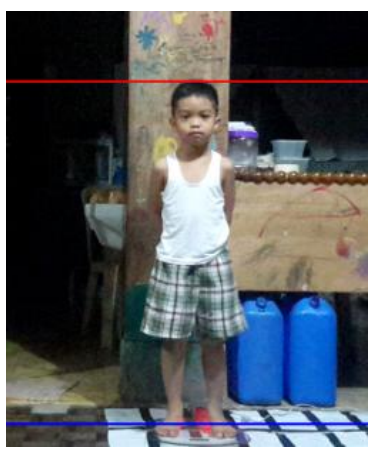

Fig. 6. Height estimation.

Fig. 6 shows the detection of the person from a background model. The line on the bottom shows the base point of the object and the difference between the top line and bottom line gives the height of the object in the image. The top line is based on the improved binary image which was the result of the background subtraction and the top most pixel was detected. The binary image was improved by eroding the image to remove the unnecessary pixels. The bottom line was detected by searching for the horizontal line on the pattern on the floor. The difference the y-coordinate of the top and bottom line is the height of the person in the image.

\section{Body Mass Index (BMI)}

The BMI was computed using (3) and its category was based on the standard BMI table by the World Health Organization (WHO).

$$
\mathrm{BMI}=\frac{W}{H^{2}}
$$

where $W$ is the weight in kilograms, $\mathrm{H}$ is the height in meters and the BMI is the Body Mass Index in $\mathrm{kg} / \mathrm{m}^{2}$.

The data obtained using the weight measurement and height estimation procedures were used to calculate the BMI of the person.

\section{RESUlTS AND DisCUSSION}

This part of the study is for the analysis of the data gathered used for computing the BMI of a person. The data were obtained using the weight measurement and height estimation procedures discussed.

For the following data, the computed vanishing point by getting the intersection of the lines was $310.4087 \mathrm{px}$ and the camera height obtained, following (2), was $0.42 \mathrm{~m}$ using a $0.335 \mathrm{~m}$ object as basis.

TABLE I: Height Measured Manually Vs. HeIGHT COMPUTEd USING

\begin{tabular}{|c|c|c|c|}
\hline & $\begin{array}{c}\text { Height } \\
\text { Measured } \\
\text { Manually (m) }\end{array}$ & $\begin{array}{l}\text { Height } \\
\text { Computed using } \\
\text { the Device }(\mathrm{m})\end{array}$ & $\begin{array}{c}\text { Percent } \\
\text { Difference }(\%)\end{array}$ \\
\hline Sample 1 & 1.15 & 1.14 & 0.91 \\
\hline Sample 2 & 1.42 & 1.40 & 1.26 \\
\hline Sample 3 & 1.6 & 1.59 & 0.57 \\
\hline Sample 4 & 1.6 & 1.60 & 0.27 \\
\hline Sample 5 & 1.64 & 1.62 & 1.16 \\
\hline Sample 6 & 1.4 & 1.39 & 0.78 \\
\hline Sample 7 & 1.65 & 1.64 & 0.53 \\
\hline Sample 8 & 1.42 & 1.40 & 1.26 \\
\hline Sample 9 & 1.34 & 1.34 & 0.35 \\
\hline Sample 10 & 1.6 & 1.61 & 0.37 \\
\hline Sample 11 & 1.37 & 1.35 & 1.25 \\
\hline Sample 12 & 1.35 & 1.35 & 0.28 \\
\hline Sample 13 & 1.15 & 1.14 & 1.20 \\
\hline Sample 14 & 1.4 & 1.39 & 0.53 \\
\hline Sample 15 & 1.6 & 1.59 & 0.36 \\
\hline Sample 16 & 1.6 & 1.59 & 0.68 \\
\hline Sample 17 & 1.55 & 1.54 & 0.91 \\
\hline Sample 18 & 1.65 & 1.65 & 0.02 \\
\hline Sample 19 & 1.6 & 1.59 & 0.36 \\
\hline Sample 20 & 1.42 & 1.40 & 1.14 \\
\hline Sample 21 & 1.64 & 1.61 & 1.77 \\
\hline Sample 22 & 1.62 & 1.60 & 1.02 \\
\hline Sample 23 & 1.15 & 1.13 & 1.49 \\
\hline Sample 24 & 1.56 & 1.54 & 1.06 \\
\hline Sample 25 & 1.55 & 1.54 & 0.63 \\
\hline Sample 26 & 1.41 & 1.40 & 0.52 \\
\hline Sample 27 & 1.35 & 1.35 & 0.08 \\
\hline Sample 28 & 1.64 & 1.62 & 0.95 \\
\hline Sample 29 & 1.65 & 1.65 & 0.12 \\
\hline Sample 30 & 1.37 & 1.37 & 0.31 \\
\hline
\end{tabular}
THE DEVICE

Table I shows that actual and computed height of the person as well as the error percentage from the obtain results. As observed from the table, the percent difference for each sample is very small. The greatest percent different was $1.77 \%$ which is very small. With the percent difference obtained, it can be said that the actual height and the computed height from the study is almost similar.

Furthermore, t-test was used to determine if there were significant differences between the values. The values that will be compared are the actual height and computed height using the proposed device. Since the calculated t-value, 0.2462 , was less than the p-value, 2.02, and the p-value, 0.8064 , was greater than the alpha, 0.05 , then, there was no sufficient evidence to reject the null hypothesis. This means that the height from the actual and computed measurements have no significant difference.

The errors are from the inaccurate positioning of the camera as well as the unnecessary inclusion hair in the height measurement. The camera must be position perpendicular to the ground. 
TABLE II: WEIGHT MEASURED MANUALLY VS. WEIGHT COMPUTED USING THE DEVICE

\begin{tabular}{|c|c|c|c|}
\hline & $\begin{array}{c}\text { Weight } \\
\text { Measured } \\
\text { Manually (kg) }\end{array}$ & $\begin{array}{l}\text { Weight } \\
\text { Computed using } \\
\text { the Device }(\mathrm{kg})\end{array}$ & $\begin{array}{c}\text { Percent } \\
\text { Difference }(\%)\end{array}$ \\
\hline Sample 1 & 18.8 & 18.7 & 0.43 \\
\hline Sample 2 & 41.8 & 41.7 & 0.26 \\
\hline Sample 3 & 64.2 & 64.2 & 0.05 \\
\hline Sample 4 & 54.3 & 54.5 & 0.28 \\
\hline Sample 5 & 53.2 & 53.2 & 0.06 \\
\hline Sample 6 & 50 & 49.8 & 0.46 \\
\hline Sample 7 & 68.5 & 68.5 & 0.01 \\
\hline Sample 8 & 41.8 & 41.7 & 0.26 \\
\hline Sample 9 & 26.8 & 26.8 & 0.00 \\
\hline Sample 10 & 54.3 & 54.5 & 0.28 \\
\hline Sample 11 & 41.8 & 41.7 & 0.26 \\
\hline Sample 12 & 39.7 & 39.6 & 0.35 \\
\hline Sample 13 & 18.8 & 18.7 & 0.43 \\
\hline Sample 14 & 50 & 49.8 & 0.46 \\
\hline Sample 15 & 54.3 & 54.5 & 0.28 \\
\hline Sample 16 & 64.2 & 64.2 & 0.05 \\
\hline Sample 17 & 54.1 & 54.0 & 0.13 \\
\hline Sample 18 & 68.5 & 68.5 & 0.01 \\
\hline Sample 19 & 64.2 & 64.2 & 0.05 \\
\hline Sample 20 & 41.8 & 41.7 & 0.26 \\
\hline Sample 21 & 53.2 & 53.2 & 0.06 \\
\hline Sample 22 & 56.7 & 56.6 & 0.21 \\
\hline Sample 23 & 18.8 & 18.7 & 0.43 \\
\hline Sample 24 & 43.9 & 43.8 & 0.18 \\
\hline Sample 25 & 54.1 & 54.0 & 0.13 \\
\hline Sample 26 & 35.4 & 35.3 & 0.25 \\
\hline Sample 27 & 39.7 & 39.6 & 0.35 \\
\hline Sample 28 & 53.2 & 53.2 & 0.06 \\
\hline Sample 29 & 68.5 & 68.5 & 0.01 \\
\hline Sample 30 & 41.8 & 41.7 & 0.26 \\
\hline
\end{tabular}

TABLE III: Body MASS INDEX (BMI) COMPUTED MANUALLY VS .BodY MASS INDEX (BMI) COMPUTED USING THE DEVICE

\begin{tabular}{lccc}
\hline \hline & $\begin{array}{c}\text { BMI Computed } \\
\text { Manually } \\
\left(\mathrm{kg} / \mathrm{m}^{2}\right)\end{array}$ & $\begin{array}{c}\text { BMI Computed } \\
\text { using the Device } \\
\left(\mathrm{kg} / \mathrm{m}^{2}\right)\end{array}$ & $\begin{array}{c}\text { Percent } \\
\text { Difference }(\%)\end{array}$ \\
\hline Sample 1 & 14.22 & 14.41 & 1.39 \\
Sample 2 & 20.73 & 21.20 & 2.25 \\
Sample 3 & 25.08 & 25.38 & 1.20 \\
Sample 4 & 21.21 & 21.16 & 0.26 \\
Sample 5 & 19.78 & 20.23 & 2.26 \\
Sample 6 & 25.51 & 25.79 & 1.09 \\
Sample 7 & 25.16 & 25.42 & 1.04 \\
Sample 8 & 20.73 & 21.20 & 2.25 \\
Sample 9 & 14.93 & 15.03 & 0.70 \\
Sample 10 & 21.21 & 21.11 & 0.47 \\
Sample 11 & 22.27 & 22.77 & 2.24 \\
Sample 12 & 21.78 & 21.83 & 0.20 \\
Sample 13 & 14.22 & 14.50 & 1.97 \\
Sample 14 & 25.51 & 25.67 & 0.61 \\
Sample 15 & 21.21 & 21.42 & 1.00 \\
Sample 16 & 25.08 & 25.43 & 1.41 \\
Sample 17 & 22.52 & 22.90 & 1.70 \\
Sample 18 & 25.16 & 25.16 & 0.02 \\
Sample 19 & 25.08 & 25.27 & 0.77 \\
Sample 20 & 20.73 & 21.15 & 2.01 \\
Sample 21 & 19.78 & 20.48 & 3.49 \\
Sample 22 & 21.60 & 22.00 & 1.83 \\
Sample 23 & 14.22 & 14.58 & 2.56 \\
Sample 24 & 18.04 & 18.39 & 1.93 \\
Sample 25 & 22.52 & 22.77 & 1.12 \\
Sample 26 & 17.81 & 17.95 & 0.79 \\
Sample 27 & 21.78 & 21.74 & 0.20 \\
Sample 28 & 19.78 & 20.15 & 1.84 \\
Sample 29 & 25.16 & 25.22 & 0.22 \\
Sample 30 & 22.27 & 22.35 & 0.35 \\
\hline \hline
\end{tabular}

Table II shows that actual and computed weight of the person as well as the error percentage from the obtain results. As observed from the table, the percent difference for each sample is very small. The greatest percent different was $0.46 \%$ which is very small. With the percent difference obtained, it can be said that the actual weight and the computed weight from the study is almost similar.

Moreover, t-test was used to determine if there were significant differences between the values. The values that will be compared are the actual weight and computed weight using the proposed device. Since the calculated t-value, 0.0139 , was less than the $\mathrm{p}$-value, 2.02 , and the $\mathrm{p}$-value, 0.9890 , was greater than the alpha, 0.05 , then, there was no sufficient evidence to reject the null hypothesis. This means that the weight from the actual and computed measurements have no significant difference.

The error came from the inaccurate values of the calibration parameters.

TABLE IV: BMI CATEGORY DETERMINED MANUALLY VS. BMICATEGORY DETERMINED USING THE DEVICE

\begin{tabular}{|c|c|c|c|}
\hline & $\begin{array}{c}\text { BMI Category } \\
\text { Determined } \\
\text { Manually }\end{array}$ & $\begin{array}{c}\text { BMI Category } \\
\text { Determined using } \\
\text { the Device }\end{array}$ & Comparison \\
\hline Sample 1 & $\begin{array}{c}\text { Underweight: } \\
\text { Severe Thinness }\end{array}$ & $\begin{array}{c}\text { Underweight: } \\
\text { Severe Thinness }\end{array}$ & Similar \\
\hline Sample 2 & Normal & Normal & Similar \\
\hline Sample 3 & $\begin{array}{l}\text { Overweight: } \\
\text { Pre-obese }\end{array}$ & $\begin{array}{l}\text { Overweight: } \\
\text { Pre-obese }\end{array}$ & Similar \\
\hline Sample 4 & Normal & Normal & Similar \\
\hline Sample 5 & Normal & Normal & Similar \\
\hline Sample 6 & $\begin{array}{l}\text { Overweight: } \\
\text { Pre-obese }\end{array}$ & $\begin{array}{l}\text { Overweight: } \\
\text { Pre-obese }\end{array}$ & Similar \\
\hline Sample 7 & $\begin{array}{l}\text { Overweight: } \\
\text { Pre-obese }\end{array}$ & $\begin{array}{l}\text { Overweight: } \\
\text { Pre-obese }\end{array}$ & Similar \\
\hline Sample 8 & Normal & Normal & Similar \\
\hline Sample 9 & $\begin{array}{l}\text { Underweight: } \\
\text { Severe Thinness }\end{array}$ & $\begin{array}{l}\text { Underweight: } \\
\text { Severe Thinness }\end{array}$ & Similar \\
\hline Sample 10 & Normal & Normal & Similar \\
\hline Sample 11 & Normal & Normal & Similar \\
\hline Sample 12 & Normal & Normal & Similar \\
\hline Sample 13 & $\begin{array}{l}\text { Underweight: } \\
\text { Severe Thinness }\end{array}$ & $\begin{array}{l}\text { Underweight: } \\
\text { Severe Thinness }\end{array}$ & Similar \\
\hline Sample 14 & $\begin{array}{l}\text { Overweight: } \\
\text { Pre-obese }\end{array}$ & $\begin{array}{l}\text { Overweight: } \\
\text { Pre-obese }\end{array}$ & Similar \\
\hline Sample 15 & Normal & Normal & Similar \\
\hline Sample 16 & $\begin{array}{l}\text { Overweight: } \\
\text { Pre-obese }\end{array}$ & $\begin{array}{l}\text { Overweight: } \\
\text { Pre-obese }\end{array}$ & Similar \\
\hline Sample 17 & Normal & Normal & Similar \\
\hline Sample 18 & $\begin{array}{l}\text { Overweight: } \\
\text { Pre-obese }\end{array}$ & $\begin{array}{l}\text { Overweight: } \\
\text { Pre-obese }\end{array}$ & Similar \\
\hline Sample 19 & $\begin{array}{l}\text { Overweight: } \\
\text { Pre-obese }\end{array}$ & $\begin{array}{l}\text { Overweight: } \\
\text { Pre-obese }\end{array}$ & Similar \\
\hline Sample 20 & Normal & Normal & Similar \\
\hline Sample 21 & Normal & Normal & Similar \\
\hline Sample 22 & Normal & Normal & Similar \\
\hline Sample 23 & $\begin{array}{l}\text { Underweight: } \\
\text { Severe Thinness }\end{array}$ & $\begin{array}{l}\text { Underweight: } \\
\text { Severe Thinness }\end{array}$ & Similar \\
\hline Sample 24 & $\begin{array}{c}\text { Underweight: Mild } \\
\text { Thinness }\end{array}$ & $\begin{array}{c}\text { Underweight: Mild } \\
\text { Thinness }\end{array}$ & Similar \\
\hline Sample 25 & Normal & Normal & Similar \\
\hline Sample 26 & $\begin{array}{c}\text { Underweight: Mild } \\
\text { Thinness }\end{array}$ & $\begin{array}{c}\text { Underweight: Mild } \\
\text { Thinness }\end{array}$ & Similar \\
\hline Sample 27 & Normal & Normal & Similar \\
\hline Sample 28 & Normal & Normal & Similar \\
\hline Sample 29 & $\begin{array}{c}\text { Overweight: } \\
\text { Pre-obese }\end{array}$ & $\begin{array}{c}\text { Overweight: } \\
\text { Pre-obese }\end{array}$ & Similar \\
\hline Sample 30 & Normal & Normal & Similar \\
\hline
\end{tabular}

Table III shows that actual and computed Body Mass Index (BMI) of the person as well as the error percentage from the obtain results. As observed from the table, the percent difference for each sample is very small. The greatest percent different was $3.49 \%$ which is very small. With the 
percent difference obtained, it can be said that the actual Body Mass Index (BMI) and the computed Body Mass Index (BMI) from the study is almost similar.

T-test was used to determine if there were significant differences between the values. The values that will be compared are the actual BMI and computed BMI using the proposed device. Since the calculated t-value, -0.2842 , was less than the p-value, 2.02, and the p-value, 0.7774, was greater than the alpha, 0.05 , then, there was no sufficient evidence to reject the null hypothesis. This means that the BMI from the actual and computed measurements have no significant difference.

The error came from the accumulated error from the height and weight.

Table IV shows the comparison between the categories of the BMI obtained from the manual and automated measurement. As observed from the table, the BMI categories from the actual and automated measurement of all the samples are all the same. This means that the automation is successful.

\section{CONCLUSION}

As a result of this study, the Body Mass Index (BMI) of the person could be computed in an Android device using image processing and wireless weight measurement.

Using a camera, the images could be processed in order to identify the foreground object in the image by applying background subtraction. The background subtraction removed the background scene in the image. The vanishing point was an important factor in the process because it allowed the image to be related to the real world. Height estimation is better if higher pixel rating was used.

The weight of the person can be measured using load cell configured to a Wheatstone bridge. The force exerted to the load cells was converted into weak electrical signal and could be amplified using an instrumentation amplifier.

With proper calibration and amplification, the signal could be read by using a microcontroller. Wireless transmission was also possible by using wireless modules such as Bluetooth module configured to transmit data.

With the obtained data from different processes, the BMI and its classification could be identified by using the standard BMI formula and the standard BMI table.

\section{ACKNOWLEDGMENT}

The authors would like to thank the people who helped in finishing the research especially those who helped in testing the system. We would also like to thank Department of Science and Technology - Engineering Research and Development for Technology (DOST - ERDT) for funding and providing the necessary materials for this research.

\section{REFERENCES}

[1] A. S. Prabuwono et al., "PC based weight scale system with load cell for product inspection," in Proc. the International Conference on Computer Engineering and Technology, 2009, vol. 1, pp. 343-346,

[2] I. Muller et al., "Load cells in force sensing analysis-Theory and a novel application," IEEE Instrumentation and Measurement Magazine, vol. 13 , no. 1, pp. 15-19, 2010.

[3] A. J. Shelley and N. L. Seed, "Approaches to static background identification and removal," in Proc. the IEE Colloquium on Image Processing for Transport Applications, 1993, pp. 6/1-6/4.

[4] L. Maddalena and A. Petrosino, "A self-organizing approach to background subtraction for visual surveillance applications," IEEE Transactions on Image Processing, vol. 17, no. 7, pp. 1168-1177, 2008.

[5] M. K. Momeni, S. C. Diamantas, F. Ruggiero, and B. Siciliano, "Height estimation from a single camera view," in Proc. the International Conference on Computer Vision Theory and Applications, 2012, pp. 358-364, vol. 1, Rome, Italy.

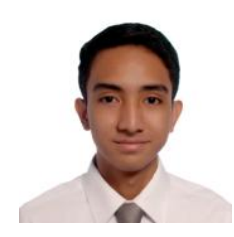

Neil Erick Q. Madariaga is a graduating student of the Computer Engineering ( $\mathrm{CpE})$ Department at Mapua Institute of Technology, Manila, Philippines. $\mathrm{He}$ is also currently pursuing his master's degree in computer engineering (MSCOE) in the same Institute. $\mathrm{He}$ is expected to finish both degrees this coming February 2015.

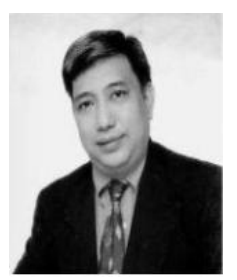

Noel B. Linsangan is the present program chair of the Computer Engineering $(\mathrm{CpE})$ Program at the Mapúa Institute of Technology, Manila, Philippines. Mapúa is the largest engineering school in the country. He obtained his baccalaureate degree in computer engineering from the same school in 1988 and his graduate degree, Master in engineering in COMPUTER Engineering from the Pamantasanng Lunsodng Maynila(University of the City of Manila) in 2000. Right after graduation from college he joined the Faculty of the Computer Engineering Program and in 2000 he was appointed as its program chair. He is part of the team that pioneered the implementation of OBE in Mapúa and also one of the point persons of the Institute when its $\mathrm{EE}, \mathrm{ECE}$, and $\mathrm{CpE}$ programs were preparing for $\mathrm{ABET}$ accreditation. 